\title{
Production of Ethanol from Sudanese Sugar Cane Molasses and Evaluation of Its Quality
}

Mohammed Abdalbasit A. Gasmalla, Ruijin Yang*, Mehdi Nikoo and Su Man

State Key Laboratory of Food Science and Technology, School of Food Science and Technology, Jiangnan University, Wuxi 214122, China

\begin{abstract}
The objective of the present study was to produce ethanol from final sugar cane molasses and to evaluate its quality. Urea was used as nitrogen source and added at different concentrations $0.15 \%, 0.5 \%$, and $0.25 \%$ $(\mathrm{w} / \mathrm{v})$ to the molasses mash. Experiments were conducted using four treatments depending upon molasses sugar concentration which was calculated as percentages $10,15,20$ and $25(\mathrm{w} / \mathrm{v})$. The $\mathrm{pH}$ of the mash was adjusted to 4.8 using concentrated sulphuric acid. $5 \%(\mathrm{w} / \mathrm{v})$ baker's yeast was added. The fermentation was conducted for 72 hours at $33^{\circ} \mathrm{C}$. The microbiological analysis revealed absence of bacteria, yeasts and moulds in dilutions 10-3, 10-4, 10-5 of molasses samples. The yield of ethanol obtained was $20 \mathrm{ml}$ per $100 \mathrm{~g}$ of molasses, and ethanol with $96 \%$ purity could be obtained when the main medium of production (molasses) includes $0.25 \%(\mathrm{w} / \mathrm{v})$ urea and $20 \%(\mathrm{w} / \mathrm{v})$ sugar concentration.
\end{abstract}

Keywords: Sugar cane; Molasses; Ethanol; Chemical composition; Fermented mash

\section{Introduction}

Ethanol known as ethyl alcohol or grain alcohol is a flammable, colorless, mildly toxic chemical compound with a distinctive perfume -like odor, and the ethanol is found in alcoholic beverages. In common usage, it is often referred to simply as alcohol [1]. Natural energy resources such as petroleum and coal have been consumed at high rates over the last decades. The heavy reliance of the modern economy on these fuels is bound to end, due to their environmental impact (and the corresponding pressure of society) and to the fact that they might eventually run out. Therefore, alternative resources such as ethanol are becoming more important. Bio-ethanol is one of the most important renewable fuels contributing to the reduction of negative environmental impacts generated by the worldwide utilization of the fossil fuels [2]. Hoefnagels et al. [3] also reviewed and examined methodological choices and premises in the estimation of the life cycle greenhouse emissions of biofuels. The properties of ethanol stem primarily from the presence of its hydroxyl group and the shortness of its carbon chain. Ethanol's hydroxyl group is able to participate in hydrogen bonding, rendering it more viscous and less volatile than less polar organic compounds of similar molecular weight. Ethanol has slightly more refractive than water with a refractive index of 1.36242 (at $\lambda=589.3 \mathrm{~nm}$ and $\left.18.35^{\circ} \mathrm{C}\right)$ [4].

Molasses, a by-product of sugar processing, is produced in large amount in Sudan. Sucrose is lost in sugarcane molasses which affect factory profit; therefore transformation of molasses to ethanol is possible alternative to maximize the use of molasses. Ethanol is extensively used as a motor fuel additive [5]. The United States became the world's largest producer of ethanol which produced 49.2 billion liters of ethanol fuel in 2010 [6]. Yeasts are the most commonly used microorganisms for ethanol fermentation. Anaerobic fermentation of Saccharomyces cerevisiae generates, besides ethanol, carbon dioxide, glycerol and cell biomass as the most significant byproducts. Carbon dioxide is an inevitable fermentation product, but the off-gas can be sold as a high-quality raw material. Glycerol can be produced as a compatible solute during osmotic stress [7]. The fermentative yeast Saccharomyces cerevisiae is largely employed in ethanol production using renewable biomass such as sugar cane, sugar beet and molasses as the main carbon source [8] because this strain exhibits typical values for fermentation parameters, such as fermentation ability in both low sugar (5\% of sugar) and high sugar (30\% of sugar) [9]. Among them, sugar-cane blackstrap molasses is a very useful raw material for that purpose, because it is cheap and plentiful in the sugar industry. The ethanol fermentation can be carried out in batch, fed-batch or continuous mode [10]. Ethanol for use in alcoholic beverages, and the vast majority of ethanol for use as fuel, is produced by fermentation. When certain species of yeast, most importantly, Saccharomyces cerevisiae, metabolize sugar in the absence of oxygen, they produce ethanol and carbon dioxide. The chemical equation below summarizes the conversion: $\mathrm{C}_{6} \mathrm{H}_{12} \mathrm{O}_{6} \rightarrow 2 \mathrm{CH}_{3} \mathrm{CH}_{2} \mathrm{OH}+2 \mathrm{CO}_{2}$ [11]. The objective of this study was to determine the effect of urea and sugar concentrations on ethanol production yield.

\section{Materials and Methods}

\section{Materials}

Molasses samples were obtained from a local sugar factory (Elguneid, Al Jazirah State, Sudan), A strain of baker's yeast (Saccharomyces cerevisia), urea, sulphuric acid, sodium hydroxide, hydrochloric acid, fehling A, fehling B, methylene blue and EDTA were purchased from Elwataneia Co. (Khartoum, Sudan).

\section{Chemical composition of black strap molasses}

The $\mathrm{pH}$ of the molasses was measured using $\mathrm{pH}$-meter (PHS-3C Digital) at ambient temperature according to ICUMSA [12]. The total soluble solids, the total sugar content and reducing sugars content were determined according to ICUMSA [12]. The sucrose content was

*Corresponding author: Ruijin Yang, State Key Laboratory of Food Science and Technology, School of Food Science and Technology, Jiangnan University, Wuxi 214122, China, Tel/Fax: +86-510-85919150; E-mail: yrj@jiangnan.edu.cn

Received June 07, 2012; Accepted July 16, 2012; Published July 20, 2012

Citation: Gasmalla MAA, Yang R, Nikoo M, Man S (2012) Production of Ethano from Sudanese Sugar Cane Molasses and Evaluation of Its Quality. J Food Process Technol 3:163. doi:10.4172/2157-7110.1000163

Copyright: $\odot 2012$ Gasmalla MAA, et al. This is an open-access article distributed under the terms of the Creative Commons Attribution License, which permits unrestricted use, distribution, and reproduction in any medium, provided the original author and source are credited. 
determined according to ICUMSA [13]. Ash content was determined according to Chen and Chou [14].

\section{Mash preparation and fermentation}

Sample (100 g) was weighed into a beaker of one-liter volume and $500 \mathrm{ml}$ of water was added to the molasses. The weight of yeast was taken to be as a percentage $5 \%(\mathrm{w} / \mathrm{v})$ of mash weight. The required nutrients (urea) of different concentrations $0.15 \%, 0.5 \%$, and $0.25 \%$ $(\mathrm{w} / \mathrm{v})$ were then added. The $\mathrm{pH}$ of the mixture was adjusted to 4.8 using concentrated sulphuric acid. The mash was transferred into clean reinforced plastic container of about $900 \mathrm{ml}$ volume. Fermentation was conducted for $72 \mathrm{~h}$ under controlled temperature. For final production, the fermented mash was distillated and the ethanol amount was recorded.

\section{Ethanol measurement}

The yield of ethanol (\%) in the fermented mash was measured using an Ebulliometer (Model 170-1652, Kessler Co., and Washington 98272, USA). The density, viscosity and purity values of ethanol were determined according to (AOAC) [15].

\section{Microbiological analysis}

Preparation of media and samples, total viable count, yeast and mould count of molasses were determined according to APHA [16].

\section{Statistical analysis}

Data were analyzed by one-way analysis of variance (ANOVA) followed by Duncan multiple range test using SPSS 16. All data were expressed as mean \pm SD. The significance of results was at $5 \%$.

\section{Results and Discussion}

\section{Chemical composition of black strap molasses}

The chemical composition of black strap molasses is presented in Table 1 . The molasses contained $84^{\circ}$ brix, $17 \%$ reducing sugars, $32 \%$ sucrose, $49 \%$ total sugars, $12.69 \%$ ash (w/v) on wet weight basis. The, $\mathrm{pH}$ value of obtained molasses was 5.8. The brix value determined in this study was lower than the value $\left(85.4^{\circ}\right)$ reported by Paturau [17]. Results indicated that chemical composition of Sudanese sugar cane molasses were in close agreement to those reported by Chen and Chou [14], who found that molasses contained $52 \%$ total sugars, $16 \%$ reducing sugars, $34 \%$ sucrose, $12 \%$ ash and $\mathrm{pH} 5.0$.

\begin{tabular}{|l|l|}
\hline Parameter & Mean $(\mathrm{w} / \mathrm{v})$ \\
\hline Brix & $84 \pm 2.51^{\circ}$ \\
\hline Reducing sugars & $17 \pm 2.0 \%$ \\
\hline Sucrose & $32 \pm 3.51 \%$ \\
\hline Total sugars & $49 \pm 5.50 \%$ \\
\hline Ash & $12.69 \pm 0.26 \%$ \\
\hline $\mathrm{pH}$ & $5.8 \pm 0.35$ \\
\hline
\end{tabular}

Table 1: Chemical composition of black strap molasses (on wet weight basis).

\begin{tabular}{|l|l|l|}
\hline Dilutions & $\begin{array}{l}\text { Total viable counts (c.f.u./ } \\
\mathrm{ml})\end{array}$ & $\begin{array}{l}\text { Yeast and mould } \\
\text { counts(c.f.u./ml) }\end{array}$ \\
\hline $10^{-1}$ & $3 \times 10^{2}$ & $2 \times 10^{2}$ \\
\hline $10^{-2}$ & $0.7 \times 10^{2}$ & $0.9 \times 10^{2}$ \\
\hline $10^{-3}$ & $\mathrm{ND}$ & $\mathrm{ND}$ \\
\hline $10^{-4}$ & $\mathrm{ND}$ & $\mathrm{ND}$ \\
\hline $10^{-5}$ & $\mathrm{ND}$ & $\mathrm{ND}$ \\
\hline
\end{tabular}

Table 2: Microbiological analysis of molasses.

\begin{tabular}{|l|l|l|l|l|l|}
\hline $\begin{array}{l}\text { Molasses } \\
\text { weight }(\mathrm{g})\end{array}$ & $\begin{array}{l}\text { Sugar } \\
\text { concentration } \\
(\%)\end{array}$ & Urea\% & $\mathrm{pH}$ & $\begin{array}{l}\text { Temperature } \\
\left({ }^{\circ} \mathrm{C}\right)\end{array}$ & $\begin{array}{l}\text { Yield\% } \\
(\mathrm{w} / \mathrm{v})\end{array}$ \\
\hline 100 & 8.3 & 0.15 & 4.8 & 33 & $4.8 \pm 0.10$ \\
\hline 100 & 8.3 & 0.50 & 4.8 & 33 & $5.5 \pm 0.15$ \\
\hline 100 & 8.3 & 0.25 & 4.8 & 33 & $5.9 \pm 0.21$ \\
\hline
\end{tabular}

Table 3: Ethanol yield in fermented mash using different urea concentrations.

\begin{tabular}{|l|l|l|l|l|l|l|}
\hline $\begin{array}{l}\text { Molasses } \\
\text { weight }(\mathrm{g})\end{array}$ & $\begin{array}{l}\text { Water } \\
\text { mash } \\
\text { added }(\mathrm{ml})\end{array}$ & $\begin{array}{l}\text { Sugar } \\
\text { concentra- } \\
\text { tion \%(w/v) }\end{array}$ & $\begin{array}{l}\text { Urea concen- } \\
\text { tration \% }(\mathrm{w} / \mathrm{v}))\end{array}$ & $\mathrm{pH}$ & $\begin{array}{l}\text { Tempera- } \\
\text { ture }\left({ }^{\circ} \mathrm{C}\right)\end{array}$ & $\begin{array}{l}\text { Yield\% } \\
(\mathrm{w} / \mathrm{v})\end{array}$ \\
\hline 100 & 300.20 & 10 & 0.25 & 4.8 & 33 & $5.5 \pm 0.20$ \\
\hline 100 & 200.20 & 15 & 0.25 & 4.8 & 33 & $7.8 \pm 0.10$ \\
\hline 100 & 100.20 & 20 & 0.25 & 4.8 & 33 & $11 \pm 0.40$ \\
\hline 100 & 70 & 25 & 0.25 & 4.8 & 33 & $10.3 \pm 0.35$ \\
\hline
\end{tabular}

Table 4: Effect of sugar concentration on ethanol yield.

\begin{tabular}{|l|l|}
\hline Properties & Mean value \\
\hline Purity $(\%)$ & $96 \pm 1.45$ \\
\hline Density $(\mathrm{g} / \mathrm{ml})$ & $0.807 \pm 0.03$ \\
\hline Viscosity $(\mathrm{cP})$ & $0.83 \pm 0.04$ \\
\hline
\end{tabular}

Table 5: Physicochemical characteristics of the obtained ethanol in this study.

\section{Microbiological analysis of molasses}

The microbiological analysis of molasses samples is shown in Table 2. The results revealed the presence of $3 \times 10^{2}$ and $0.7 \times 10^{2}$ (c.f.u/ml) of total microbial counts in $10^{-1}$ and $10^{-2}$ molasses residual dilution, respectively. While other dilutions $\left(10^{-3}, 10^{-4}\right.$ and $\left.10^{-5}\right)$ were devoid of microorganisms, it seems that the high sugar concentration reduced the total number of microorganisms as a result of reduction in water activity. On the other hand, the yeast and mould counts at dilutions of molasses $10^{-1}$ and $10^{-2}$ were found to be $2 \times 10^{2}$ and $0.9 \times 10^{2}$ (c.f.u/ $\mathrm{ml})$, respectively while other dilutions of molasses $\left(10^{-3}, 10^{-4}\right.$ and $\left.10^{-5}\right)$ were free from yeast and moulds. This could be attributed to the good hygienic conditions during sampling.

\section{Effects of nutrient concentration on the yield of ethanol in fermented mash}

The effect of different urea concentrations $(0.15 \%, 0.50 \%$, and $0.25 \%$ ) on ethanol yield from fermented molasses mash is shown in Table 3. The highest nutrient concentration which gave the highest ethanol yield in fermented mash after period of fermentation (72 hours) was $0.25 \%(\mathrm{w} / \mathrm{v})$. Calm [18] reported that the use of $\left(\mathrm{NH}_{4}\right) 2 \mathrm{SO}_{4}$ as a nitrogen source in molasses medium is greatly recommended for ethanol production.

\section{Effects of sugar concentration on the yield of ethanol in fermented mash}

Sugar concentration plays an important role in ethanol fermentation by yeast. For economic reasons the residual sugar for maximum ethanol formation should be negligible at the end of fermentation. Therefore, the optimum level of sugar was determined by using $20 \%(\mathrm{w} / \mathrm{v})$ sugar in molasses medium (Table 4). Maximum amount of ethanol 11\% (w/v) was produced when the sugar concentration was $20 \%$ (w/v). Further increase in the sugar concentration, however, resulted in the decrease of its conversion to ethanol. The decrease in fermentation efficiency by increasing the sugar level above $20 \%$ may be due to the substrate inhibition or due to the increased accumulation of residual sugar [19]. Monot et al. [20] studied the effect of sugar in synthetic medium. The workers found the yield of ethanol was maximum when sugar level 
Citation: Gasmalla MAA, Yang R, Nikoo M, Man S (2012) Production of Ethanol from Sudanese Sugar Cane Molasses and Evaluation of Its Quality. J Food Process Technol 3:163. doi:10.4172/2157-7110.1000163

Page 3 of 3

ranged from 4.0 to $6.0 \%(\mathrm{w} / \mathrm{v})$. The volume of ethanol production was $20 \mathrm{ml}$ per $100 \mathrm{~g}$ of molasses.

\section{Physicochemical characteristics of ethanol}

In Table 5 physicochemical characteristics of ethanol was shown. Ethanol had $96 \%$ purity, $0.80 \mathrm{~g} / \mathrm{ml}$ density and $0.83 \mathrm{cP}$ viscosity. The purity value determined in this study was slightly greater than the most popular method of purification in which the purity reached 95.6\% [21]. The bio-ethanol produced by Ghosh and Ghose [22] was in the form of hydrous ethanol $(95 \% \mathrm{v} / \mathrm{v})$. The density value was higher than the standard density value $(0.78097 \mathrm{~g} / \mathrm{ml})$ in the same temperature [23]. The viscosity value was greater than the value $0.37 \mathrm{cP}$ reported by Perry's [5].

\section{Conclusion}

Experimental results of producing ethanol from molasses showed high alcohol yield, especially when urea (as a nutrient source) and sugars were used at $0.25 \%$ and $20 \%(\mathrm{w} / \mathrm{v})$ concentrations, respectively. That formulation gave $11 \%(\mathrm{w} / \mathrm{v})$ ethanol in fermented mash. After distillation, the volume of ethanol produced was $20 \mathrm{ml}$ per $100 \mathrm{~g}$ of molasses, these conditions were considered suitable for yeast activity and high yield of alcohol.

\section{Acknowledgments}

The authors would like to thank the Elguneid Co. for providing the samples and help with the sample processing. We are also grateful to Prof. Kamal Suleiman, the dean of sugar institute of the University of Gezira for kindly reviewing the manuscript.

\section{References}

1. Rao RS, Prakasham RS, Prasad KK, Rajesham S, Sarma PN, et al. (2004) Xylitol production by Candida sp. Parameter optimization using Taguchi approach. Process Biochem 39: 951-956.

2. Cardona CA, Sánchez OJ (2007) Fuel ethanol production: process design trends and integration opportunities. Bioresour Technol 98: 2415-2457.

3. Hoefnagels R, Smeets E, Faaij A (2010) Greenhouse gas footprints of different biofuel production systems. Renew Sustain Energ Rev 14: 1661-1694.

4. Lide DR (2000) CRC handbook of chemistry and physics. 8th ed CRC press.

5. Perry's RH (1987) Chemical Engineers' Handbook, (6thEdn), International student edition, McGraw-Hill Chemical Engineering Services.

6. Lichts FO (2011) Industry Statistics: 2010 World fuel Ethanol Production, Renewable Fuels Association. Retrieved 2011-04-30.

7. Brandberg T, Gustafsson A, Franzén CJ (2007) The impact of severe nitrogen limitation and microaerobic conditions on extended continuous cultivations of Saccharomyces cerevisiae with cell recirculation. Enzym Microb Technol 40: $585-593$

8. Laluce C (1991) Current aspects of fuel ethanol production in Brazil. Critic Rev Biotechnol 11: 149-161.

9. Nishida O, Kuwazaki S, Suzuki C, Shima J (2004) Superior molasses assimilation, stress tolerance, and trehalose accumulation of baker's yeast isolated from dried sweet potatoes (hoshi-imo). Biosci Biotechnol Biochem 68 1442-1448.

10. Vitolo M (1996) Production of ethanol and invertase by S. cerevisiae grown in blackstrap molasses.

11. Morias PB, Rosa CA, Linardi VR, Carazza F, Nonato EA (2007) Production of fuel alcohol by Saccharomyces starins from tropical habitats. Biotechnol Lett 18: $1351-1356$

12. ICUMSA (International Commission Uniform Methods of Sugar Analysis). Method book with first supplement. (1998).

13. ICUMSA (International Commission Uniform Methods of Sugar Analysis). Method book with first supplement. (1994)

14. Chen CP, Chou CC (1993) Cane sugar handbook, a manual for cane sugars manufactures and their chemists. John Willey and Sons, Inc., New York.

15. AOAC (1990) Official Methods of Analysis, (15thedn), Association of Official American Chemists, Washington DC, USA.

16. APHA (1984) Compendium of methods for the microbiological examination of foods, (2ndedn), M. L. Speck, ed. 663-681, American Public Health Association, Washington DC.

17. Paturau JM (1989) By-product of the cane sugar industry, an Introduction to their industrial utilization, third completely revised edition. Elsevier, Amsterdam, Oxford, New York, Tokyo.

18. Calm CT (1980) Effect of inorganic nitrogen sources. Biotechnol Lett 2: 111 116.

19. Sedha RK, Verma GG (2002) Ethanol fermentation from molasses using cell recycling of S. cerevisiae. J Ferment Technol 345-352.

20. Monot F, Martin JP, Petitdemange H, Gay R (1982) Acetone and butano production by Clostridium acetobutylicum in a synthetic medium. Appl Environ Microbial 44: 1318-1324

21. Mills GA (2007) Alcohols as components of transportation fuels. Annu Rev Energ 12: 47-80.

22. Ghosh P, Ghose TK (2003) Bioethanol in India: recent past and emerging future. In Advances in Biochemical Engineering/Biotechnology (T Scheper, S Belkin, W Zhou, JJ Zhong, ed.), pp. 1-27.

23. Dean JA (1999) Lange's handbook of chemistry (15thEdn). McGraw-Hill, New York, USA. 